\title{
sciendo
}

Research Article

(C) 2019 Sampieri-Cabrera et.al. This is an open access article licensed under the Creative Commons Attribution-NonCommercial-NoDerivs License (http://creativecommons.org/licenses/by-nc-nd/3.0/).

\section{How Can Collaborative Learning Be Applied in Undergraduate Courses in Health Sciences?}

\author{
R. Sampieri-Cabrera \\ LF Sosa-Romano
}

\section{Inclán-Rubio}

Departamento de Fisiología, Facultad de Medicina, UNAM

Doi: 10.2478/jesr-2019-0040

\section{Abstract}

The use of collaborative learning in the classroom or on virtual platforms has been demonstrated in the multiple works of educational research, the results are conclusive, the students that deal with the capacity of reasoning, the retention of concepts, communication skills and the organization, among others. In the health sciences, it is essential to work in the team, health services are in collaboration and the formation of multidisciplinary working groups. Doctors, nurses, pharmacists, biochemists, social workers, psychologists, among others, they must develop oral and written communication skills and be able to give medical advice that contributes to the patient's health. In other words, the very nature of medicine emanates from the social sciences and clinics and understands the patient as a subject with multiple needs, which can only be met by a team working with a common goal and collaboration to achieve it. We must teach students of health sciences to work collaboratively, the time to do it is during their school education, in simulated environments, so that, in clinical practice, they can form work teams that contribute to improving the condition of health of its population. That is why, in this work we reflect on the academic needs involved in the application of collaborative learning in undergraduate courses in health sciences.

Keywords: collaborative learning, undergraduate, learning environment

\section{Introduction}

"No man is an island" by John Donne, is the reference that characterizes our study. This phrase is applicable to many aspects of the life of humans, from the social environment to the philosophical environment, It is in fact our interconnection with the universe. This interconnection with others makes us creators of culture, something fundamental for the development of humanity.

It is very logical to think that human have the capacity to think and decide for ourselves, to elaborate products and to develop our life without the need to live with another human. However, it has been reported that quality of life increases when people live together (21), it has also been observed that it increases the release of neurotransmitters that trigger stimulating responses (12), as well as a greater expression of dendritic spines (18). Undoubtedly humans have favorable physiological responses when they are in harmonious coexistence with another humans. In addition to this, it has been reported that individuals increase their reasoning capacity and their learning when they are collaborating with each other (4).

This process of learning with the help of another partner is known as collaborative learning. Learning with the help and collaboration of other students has obtained surprising results in 
different areas of the sciences and humanities (15), this is because when collaborating with other students a learning environment is generated that stimulates their curiosity, which causes the students not to they feel inhibited by the presence of a figure of command (teacher), and let their ideas flow, without fear of making mistakes.

Now that we know what collaborative learning is, it is important to mention some differences between traditional learning vs collaborative learning:

Table 1. Comparison between the traditional and collaborative teaching-learning process.

\begin{tabular}{|c|c|c|}
\hline & $\begin{array}{l}\text { Teaching learning process } \\
\text { Traditionalist }\end{array}$ & $\begin{array}{l}\text { Teaching-Learning Process } \\
\text { Collaborative }\end{array}$ \\
\hline Learning conception & Learning is an individual act. & $\begin{array}{l}\text { Learning is a social act and is the result of } \\
\text { collegiate work }\end{array}$ \\
\hline Role of the teacher & $\begin{array}{l}\text { It is the one that gives structure and } \\
\text { determines the work that each } \\
\text { student performs. }\end{array}$ & $\begin{array}{l}\text { Is a mediator or facilitator of the teaching- } \\
\text { learning situation }\end{array}$ \\
\hline Role of the Student & $\begin{array}{l}\text { It is visualized as a person who must } \\
\text { acquire knowledge. } \\
\text { (Listen, watch, take notes) }\end{array}$ & $\begin{array}{l}\text { It is visualized as a person who actively } \\
\text { participates (Solves problems, contributes } \\
\text { and discusses) }\end{array}$ \\
\hline Authority & $\begin{array}{l}\text { Exercised by the teacher and focused } \\
\text { on discipline (focused on obeying the } \\
\text { rules and punishing) }\end{array}$ & $\begin{array}{l}\text { Freedom to propose rules, are established in } \\
\text { collegiate with the educational community }\end{array}$ \\
\hline $\begin{array}{l}\text { Objective of } \\
\text { education }\end{array}$ & $\begin{array}{l}\text { Achieve intellectualization } \\
\text { (Encyclopedism) }\end{array}$ & $\begin{array}{l}\text { Build knowledge from what each one } \\
\text { contributes with their knowledge, skills and } \\
\text { attitudes for a common achievement }\end{array}$ \\
\hline Educational process & $\begin{array}{l}\text { Knowledge transfer by repetition } \\
\text { (Verbalism and passivity) }\end{array}$ & $\begin{array}{l}\text { Participatory (Students learn in interaction } \\
\text { with their peers and facilitators) }\end{array}$ \\
\hline $\begin{array}{l}\text { Position in the } \\
\text { educational } \\
\text { community }\end{array}$ & $\begin{array}{l}\text { There is a hierarchical relationship. } \\
\text { (Distant attitude between teacher and } \\
\text { student) }\end{array}$ & $\begin{array}{l}\text { There are roles for the performance of } \\
\text { activities. } \\
\text { Attitude of trust between teacher and } \\
\text { students }\end{array}$ \\
\hline $\begin{array}{l}\text { Level of } \\
\text { commitment }\end{array}$ & $\begin{array}{l}\text { Individual commitment as a basis for } \\
\text { independence. }\end{array}$ & $\begin{array}{l}\text { ndividual and collective responsibility as a } \\
\text { basis for learning interdependence }\end{array}$ \\
\hline $\begin{array}{l}\text { Educational } \\
\text { relationship }\end{array}$ & $\begin{array}{l}\text { The teacher is visualized as the only } \\
\text { source of authority and knowledge }\end{array}$ & $\begin{array}{l}\text { Parents, and the community, are visualized } \\
\text { as additional sources of authority and } \\
\text { knowledge }\end{array}$ \\
\hline $\begin{array}{l}\text { Responsibility for } \\
\text { the task }\end{array}$ & $\begin{array}{l}\text { Assumed by the teacher when } \\
\text { structuring the work, what makes him } \\
\text { think that the group will learn }\end{array}$ & $\begin{array}{l}\text { The group adopts the responsibility of } \\
\text { learning and the teacher is a facilitator and } \\
\text { companion of the experience }\end{array}$ \\
\hline School environment & Compete with your peers & $\begin{array}{l}\text { Collaborate with your peers, and add your } \\
\text { efforts in terms of skills, knowledge and } \\
\text { attitudes (Promotes empathy and affectivity) }\end{array}$ \\
\hline $\begin{array}{l}\text { Achievement } \\
\text { orientation }\end{array}$ & $\begin{array}{l}\text { The personal achievement and level } \\
\text { of knowledge is the most important }\end{array}$ & $\begin{array}{l}\text { Complete the activity with a high level of } \\
\text { satisfaction for the student, for contributing to } \\
\text { the achievement of the task }\end{array}$ \\
\hline
\end{tabular}

Collaborative learning is understood as orientation, framework and environment for a specific process of teaching-learning that involves interdependent activities, facilitated through social interactions that support the construction of shared knowledge and problem solving (6).

A crucial determinant of the success or failure of collaborative learning in a group depends on interventions between classmates and teacher feedback. It has been demonstrated that feedback between peers leads to a better behavior in teamwork and a better capacity for self-evaluation. In the feedback process, one must be careful in the language used, it must not be aggressive or very eloquent, so as not to affect the performance of the students. In other words, a critical and objective feedback must be provided, so that the student can continue to grow professionally in an environment of trust (24). 
Collaborative learning can be guided if the participants have previously reviewed the topics that will be studied in the class. If the participants previously review the topics and have any questions, these can be resolved by other members of the group, at this time we say that the collaboration is superior to individual learning. In contrast, if the members of the group do not previously review the topics, then collaborative learning is redundant, but we can not say that it is inferior to individual learning, because when the subject was not reviewed previously, there was no individual learning. (20).

Then, the success of group work depends on: the ability of students to communicate professionally, the information they have at the time of the discussion, the level of analysis that is developed and the motivation to learn (11). Collaborative learning, then, goes beyond a learning style and seeks to generate a dialogue and discussion on a topic to analyze it from different points of view.

\section{Methodology}

An information search was carried out in PubMed, Web of Sciences, Wiley Online Librery, ERIC, Scopus and Directory Open Accesses System databases. The following words were used as a filter: Collaborative Learning, Health Sciences, undergraduate. Out of the total of 25000 results, a second filter was made to select only the works that correlate with the word "classroom", we obtained 200 results, of which the titles and / or abstracts were read and the related works were selected with the aim of this work.

We selected 25 articles that were discussed by the authors in 5 work sessions. Each author made a reflection of the works discussed and together we prepared the manuscript.

\section{Discussion}

In the health sciences, collaborative learning has developed in an innate manner in clinical health schemes, continuing education and professional training programs (7, 14). However, in basic science courses, it needs, stimuli and scenarios (provided by teachers) that facilitate collaboration in the classroom (16). Being able to provide the necessary stimuli and scenarios is the main challenge for academics and the schools of undergraduate courses in the area of health.

Based on the above, we consider that to implement collaborative learning in undergraduate programs, it is necessary at least:

- Classrooms and furnitures that facilitate interaction between students and the teacher

- Training courses for teachers and refresher courses for teachers, which provide academics with the tools to execute the program correctly

- Induction courses for students to learn to collaborate with each other

- Design of practices and learning outcomes applicable to the development of collaborative learning

- Generation of didactic material that facilitates interaction among students

- Use a code of respect for collaborative work

- Responsibility of the students to learn

- Academics' responsibility to promote collaborative learning

- Development of evaluation tools focused on collaborative learning

These are just some of the many things that should be considered for the development of collaborative learning.

In the health sciences, many of the subjects of the basic area that are taught are theoreticalpractical, this favors being able to implement collaborative learning in the classroom and / or laboratory, through sessions of conferences by team (22), reports of practical sessions by team, group sessions of discussion of results, presentation of posters, among others. In addition, a personal challenge is generated in students when they work outside of their comfort zones. (1). 
In the clinical area of health sciences, collaborative learning is present throughout the training, since students spend more time together, which increases the links between them and therefore collaborative learning, this can contribute to improve their abilities to recognize and manage health problems in hostile clinical environments (25).

Learning through collaboration and learning to collaborate are very different things from one another, the first is what we have been talking about during the development of this work and the second is a challenge for many students, that if overcome can impact on they personal relationships and in the diversity of people with whom they can interact (2).

Learning to collaborate requires:

- Aptitude for collaboration

- Empathy for the result of collaboration

- Empathy between students and teachers

- Clear objectives of collaboration

When students learn with others, they have the emotional and intellectual support that allows them to go beyond their knowledge and skills to achieve academic goals $(23,8)$, When students take group exams, the understanding of educational materials increases $(9,3)$ and this can result in higher academic achievement, more positive relationships among students, a better psychological well-being and a constructive atmosphere in the classroom (19). These results represent the majority of the students, but we should not forget that the groups are heterogeneous and in them different personalities coexist, for some, the transition to collaborative learning must be gradual, so that their adaptation is achieved during the course of the academic year. For this group of students, the teacher must create a balance between the group sessions and the Interaction dynamics, with the purpose of gradually incorporating students in collaborative learning (17).

Collaborative learning can be developed in virtual environments (13) providing students and teachers with opportunities to (10):

- Participate in joint tasks

- Communicate with each other

- Share resources

- Participate in productive processes of collaborative learning

- Participate in co-construction

- Monitor and regulate collaborative learning

- Find and build groups and communities

Teachers seek that students develop theoretical and practical knowledge that are useful in their disciplines or in their professional and personal lives, for this they can use different teachinglearning tools in the classroom or in virtual learning environments. However, the design and implementation of sessions where learning is encouraged requires support to translate knowledge about collaborative learning into an effective practice (5).

\section{Conclusion}

Collaborative learning is an innate process in humans, we tend to be dynamic, we are students and teachers at the same time. We ask ourselves and we respond individually and in teams. We believe that what is needed to implement collaborative learning in undergraduate courses is a change in the environment, that is, the environment in which students perform and this involves social, family and school aspects. Our task as teachers is great and involves multiple activities, however, it is a noble career that allows us to measure the impact of our work directly, through the results that students obtain, the level of satisfaction with the course and achievement academic goals.

\section{References}

Berger, S., Whelan, B., Mahler, C., Szecsenyi, J., Krug, K. (2018). Encountering complexity in collaborative learning activities: an exploratory case study with undergraduate health professionals. J Interprof Care, 25, 1-7. doi: 10.1080/13561820.2018.1562423

Chad, N. L., Culver, K. C. \& Teniell L. T. (2018). How Collaborative Learning Enhances Students' Openness to Diversity. The Journal of Higher Education, 89, 6, 935-960. doi: 10.1080/00221546.2018.1442638 
Chen, C.M. \& Kuo, C.H. (2019). An optimized group formation scheme to promote collaborative problem-based learning. Computers \& Education. 133, 94-115. doi: 10.1016/j.compedu.2019.01.011

Clark, A.M., Anderson, R.C., Kuo, L. (2003). Collaborative Reasoning: Expanding Ways for Children to Talk and Think in Sch. Educational Psychology Review, 15: 181. doi.org/10.1023/A:1023429215151

De Hei, M.S., Strijbos, J.W., Sjoer, E., Admiraal, W. (2015). Collaborative learning in higher education: lecturers' practices and beliefs. Research Papers in Education, 30:2, 232-247. doi: 10.1080/02671522.2014.908407

Dooly, M. (2018). Collaborative learning. Teaching and tecnology. The TESOL Encyclopedia of English Language Teaching. doi: 10.1002/9781118784235.eelt0394

Harvey, S., Uren, C.D. (2018). Collaborative learning: Application of the mentorship model for adult nursing students in the acute placement setting. Nurse Educ Today, 2018, 74, 38-40. doi: 10.1016/j.nedt.2018.11.022

Hayashi, Y. (2019). Multiple pedagogical conversational agents to support learner-learner collaborative learning: Effects of splitting suggestion types. Cognitive Systems Research. 54, 247-257. doi:10.1016/j.cogsys.2018.04.005

Hendrickson, J.M., Brady, M.P., \& Algozzine, B. (1987). Peer mediated testing: the effect of an alternative testing procedure in higher education. Educ Psychol Res, 7, 91-10.

Jeong, H., \& Hmelo-Silver, E.C. (2016). Seven Affordances of Computer-Supported Collaborative Learning: How to Support Collaborative Learning? How Can Technologies Help?, Educational Psychologist, 51:2, 247-265. doi: 10.1080/00461520.2016.1158654

Laakkonen J., Muukkonen H.,(2018). Fostering Students' Collaborative Learning Competencies and Professional Conduct in the Context of Two Gross Anatomy Courses in Veterinary Medicine. Anatomical science education, 12:2, 54-163. doi:10.1002/ase.1811

Lavazza, A. (2016). Happiness, Psychology, and Degrees of Realism. Frontiers in psychology, 7, 1148. doi:10.3389/fpsyg.2016.01148

Liao, C.W., Chen, C.H., Shih, S.J. (2019). The interactivity of video and collaboration for learning achievement, intrinsic motivation, cognitive load, and behavior patterns in a digital game-based learning environment. Computers \& Education, 133, 43-55. doi: 10.1016/j.compedu.2019.01.013

LoSavio, S. T., Dillon, K.H., Murphy, R.A., Goetz, K., Houston, F., Resick, P.A. (2019 ). Using a Learning Collaborative Model to Disseminate Cognitive Processing Therapy to Community-Based Agencies. Behav Ther, 50, 1, 36-49. doi: 10.1016 / j.beth.2018.03.007

Marjan, L., and Mohammad G. (2012). Benefits of collaborative learning. Procedia-Social and Behavioral Sciences, 2012, 31, 486-490. doi.org/10.1016/j.sbspro.2011.12.091

McHugh, D., Hall, J., McLeod, K.M., Kovelowski, C.J., Payne, A.M. (2019). Twelve tips for developing and implementing curriculum in dedicated 'collaborative classrooms'. Med Teach, 20, 1-6. doi: 10.1080/0142159X.2018.1551992

Pöysä-Tarhonen, J., Care, E., Awwal, N., Häkkinen, P. (2018 ). Pair interactions in online assessments of collaborative problem solving: case-based portraits. Res Pract Technol Enhanc Learn, 13, 1:12. doi: 10.1186/s41039-018-0079-7

Qiao, H., Li, M. X., Xu, C., Chen, H. B., An, S. C., \& Ma, X. M. (2016). Dendritic Spines in Depression: What We Learned from Animal Models. Neural plasticity. Doi:10.1155/2016/8056370

Rao, S.P., Collins, H.L., \& DiCarlo, S.E. (2002). Collaborative testing enhances student learning. Adv Physiol Educ, 26, 37-44. doi.org/10.1152/advan.00032.2001

Retnowati E, Ayres P., Sweller J., (2018). Collaborative learning effects when students have complete or incomplete knowledge. Applied Cognitive Psychology. 32:6, 681-692. doi:10.1002/acp.3444

Rondón-García, L. M., \& Ramírez-Navarrro, J. M. (2018). The Impact of Quality of Life on the Health of Older People from a Multidimensional Perspective. Journal of aging research, 2018, 1-7. doi:10.1155/2018/4086294

Schmulian, A., Coetzee, S.A. (2019). Students' experience of team assessment with immediate feedback in a large accounting class. Assessment \& Evaluation in Higher Education. 44:4, 516-532. doi: 10.1080/02602938.2018.1522295

Silberman, M. (1996). Active Learning: 101 Strategies to Teach Any Subject. Philadelphia, PA: Allyn and Bacon, 1996. URL: https://eric.ed.gov/?id=ED424243

Sridharan, B.,Boud, D. (2019). The effects of peer judgements on teamwork and self-assessment ability in collaborative group work. Asseessment \& Evaluation in Higher Education. 44:6, 894-909. doi: 10.1080/02602938.2018.1545898

Trimmer, W., Fuller, C., Kake, C., Asbury, E. (2019). Collaborative Primary Mental Health Education for Correctional Nurses. J Correct Health Care, 7. doi: 10.1177/1078345818819885 